\title{
Extent and dynamics of the Saalian ice-sheet margin in Neple, eastern Poland
}

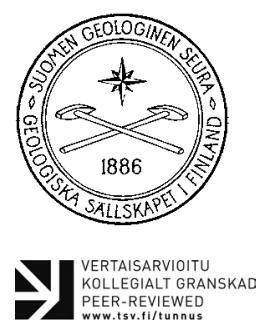

\author{
JeRZy NitychoruK ${ }^{\mathrm{I}}$, ŁUKASZ ZBUCKi ${ }^{\mathrm{I}}$, JOANNA RYCheL ${ }^{2}$, \\ Barbara Woronko ${ }^{3}$ and LesZek Marks ${ }^{2,3}$ \\ ${ }^{1}$ Pope John Paul II State School of Higher Education, Sidorska 95/97, 21-500 Biata \\ Podlaska, Poland \\ ${ }^{2}$ Polish Geological Institute, National Research Institute, Rakowiecka 4, 00-975 Warsaw, \\ Poland \\ ${ }^{3}$ Faculty of Geology, University of Warsaw, Żwirki i Wigury 93, 02-089 Warsaw, Poland
}

\begin{abstract}
The Neple site is located on a marginal moraine between the valleys of Bug and Krzna rivers in the southern part of the Polish-Belarusian border area. A glacial diamicton is overlain there by glaciofluvial sand and gravel. The glacial diamicton is laminated and, based on petrographic examination, it was ascribed both to the Sanian 2 Glaciation (Elsterian) and the Warta Stadial ice-sheet of the Odranian Glaciation (Saalian). The sediments were glaciotectonically deformed during readvance of the Warta Stadial icesheet. A local stress field was from the northwest and north but it partly encountered resistance from the glacial lobe located in the present-day river-mouth of the Krzna River. Similar glaciotectonic deformations are common also along the southwestern slope of the present Bug River valley, demarcating the maximum extent of the Warta Stadial (Saalian) ice-sheet in this area.
\end{abstract}

Keywords: Saalian Glaciation, ice-sheet limit, glaciotectonic deformation, glacial diamicton, Poland

*Corresponding author (e-mail: joanna.rychel@pgi.gov.pl)

Editorial Handling: Pertti Sarala (pertti.sarala@gtk.fi)

\section{Introduction}

The ice-sheet limit during the Warta Stadial of the Odranian Glaciation (Saalian, MIS 6) in eastern Poland and western Belarus has been debated for a long time (Tsapenko \& Makhnach, 1959; Baraniecka et al., 1984; Galon \& Roszkówna, 1961; Matveyev, 1995; Terpiłowski \& Dobrowolski, 2004; Marks \& Pavlovskaya, 2006; Marks et al., 2018). This limit was demarcated based on 
geomorphological and geological investigations (Fig. 1a). There are no distinct end moraines in this area, but the ice-marginal zone is characterized by glaciotectonic deformations of the underlying sediments (Nitychoruk et al., 2007a). In the key sites of the Mazovian Interglacial (Holsteinian) e.g. Lipnica, Pokinianka, Mokrany Nowe (Fig. 1a), lake sediments are not covered with Saalian glacial deposits. This proves that the ice-sheet of the Saalian Glaciation must have not reached these paleolakes (Nitychoruk et al., 2007a; Marks \& Karabanov, 2017). In eastern Poland and western Belarus, the Saalian ice sheet is represented by a single layer of glacial diamicton that occurs to the north of Biała Podlaska town and in the vicinity of Brest town (Fig. 1a). End moraines in this area were mostly eroded by glacial meltwaters, and even more so to the east, where the scattered remains of the glacial landscape make the demarcation of the ice-sheet limit rather difficult (Nitychoruk, 2007a, 2007b). Numerous studies performed in the marginal zone of the Warta Stadial ice-sheet of the Odranian Glaciation (Saalian) in central and eastern Poland have proved that the ice-sheet front was unstable and, therefore, the glacial diamicton and the glaciotectonic deformation of deposits were described as formed in the immediate vicinity of the ice-sheet edge (Klatkowa, 1996; Ber, 2006; Rdzany, 2009; Woronko et al., this volume). An example of the marginal zone of this ice-sheet in eastern Poland is the Neple area (Marks et al., 2018). The relief of the area features distinctive hills that tower over the plain extending to the SE and over the Krzna River valley (Fig. 1). Previous research has shown that they are partly built of glacial diamicton TLdated at $172 \pm 26 \mathrm{ka} \mathrm{BP}$, and thus correlated with the Odranian (Saalian) Glaciation (Nitychoruk, 1994). At the same time, the hills in Neple were recognized as dead-ice moraines (Nitychoruk et al., 2007b). Such interpretation was based on analysis of the topography. The hills are surrounded by a vast oval basin, previously identified as a deadice depression that is currently used by the Krzna River. Furthermore, the outcrop in Neple shows glaciotectonically deformed deposits building the hills (Nitychoruk, 1994). The origin of these deformations was associated with a static pressure of dead-ice blocks on the substrate deposits and with sediment deformation in their marginal zone (Nitychoruk \& Gałązka, 1994; Nitychoruk et al., 2007b). Furthermore, the performed petrographic analysis has revealed two types of glacial diamicton (glacial till) of different age associated with the Sanian 2 Glaciation (Elsterian, MIS 12) and the Warta Stadial of the Odranian Glaciation (Saalian, MIS 6) (Gałązka, 2004; Czubla et al., 2013).

The Neple site was again the object of research performed by Leszek Marks and his team in 2014-2017. This study focused on revision of previous results, in particular with regard to presence of deposits that represent the Warta Stadial of the Odranian Glaciation at Neple site, and verifying the maximum extent of this glaciation. Cartographic, geophysical, sedimentological and petrographic studies, as well as drilling and OSL age determinations were performed. The obtained results proved that the ice-sheet of the Saalian Glaciation in the Neple area formed a marginal zone during its maximum extent in eastern Poland (Marks et al., 2018). At the same time, results of petrographic analysis of a glacial diamicton at Neple and other sites in the Bug valley region (Marks et al., 2018), as well as documented sites with Mazovian Interglacial (Holsteinian) deposits with no glacial diamicton cover located west of the Bug River, allowed to revise the maximum extent of the Warta Stadial ice-sheet of the Saalian (MIS 6) in eastern Poland (Marks et al., 2018) (Fig. 1a) and to track dynamics of this ice-sheet front during its maximum extent.

\section{Study area}

The Neple site is located in eastern Poland, close to the border with Belarus in the vicinity of Biała Podlaska and Janów Podlaski (Fig. 1a). It is a gravel pit located within a narrow patch of the morainic plateau between the Bug and Krzna River valleys. The plateau slopes are steep and intersected by 


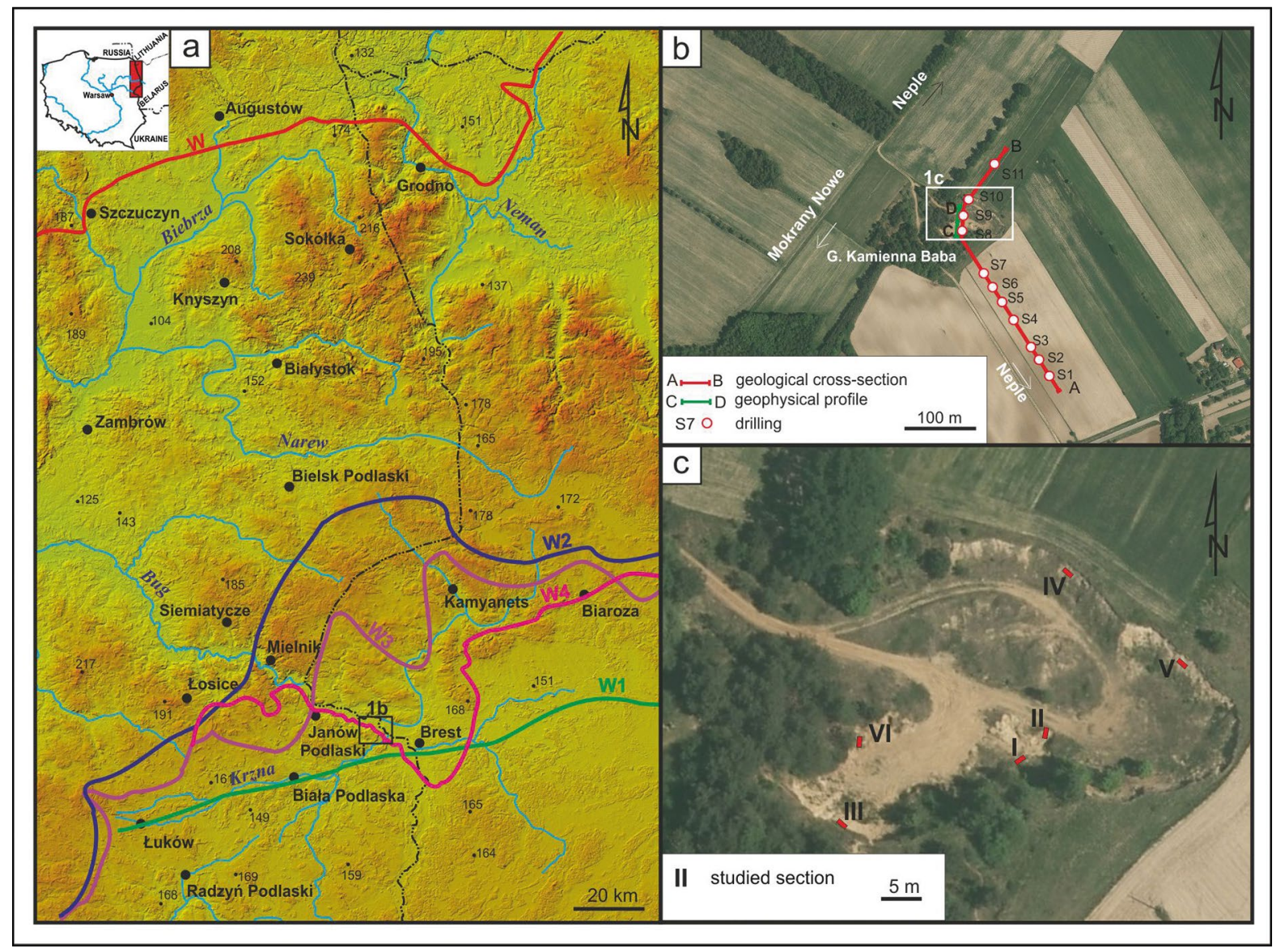

Figure 1. Location sketch: a) Warta/Sozh Stadial ice-sheet limit in western Poland and eastern Belarus after: W1 Tsapenko \& Makhnach (1959) and Baraniecka et al. (1984), W2 - Galon \& Roszkówna (1961) and Matveyev (1995), W3 - Mojski (1972) and Marks \& Pavlovskaya (2006), W4 - Marks et al. (2018) (W = Weichselian); b) An aerial image of the Neple site with the locations of geological and geophysical cross-sections indicated (cf. Fig. 3). c) An aerial image of the Neple outcrop and the gravel pit with the locations of the examined logs indicated. Fig. 1a is based on SRTMShuttle Radar Topography Mission and Figures 1b and 1c are based on photogrammetric photo flights no. 29 1532.

numerous gullies. The Neple site is located at the curve of Bug River valley that changes its direction from $\mathrm{S}-\mathrm{N}$ to $\mathrm{E}-\mathrm{W}$ in the vicinity of Neple and is joined by its left tributary, the Krzna River. In this area, the maximum limit of the penultimate glaciation (Saalian) was identified, represented by the Warta Stadial of the Odranian Glaciation (Marks et al., 2018). The Neple pit is located in the upper part of the moraine hill known as the Kamienna Baba Mount (159.28 m a.s.l.). A twolevel excavation with a total height of $5 \mathrm{~m}$ was examined at Neple (Fig. 1c.).

\section{Materials and Methods}

\subsection{Lithological analysis}

Detailed lithological analysis was performed for all documented sedimentary profiles. Lithofacies analysis was recorded in lithological and lithofacies profiles with a description of lithofacies, taking into account the nature of the contact between them (cf. Zieliński \& Pisarska-Jamroży, 2012). In the case of deformed sediments, directions of the fault plane inclination were measured to reconstruct 


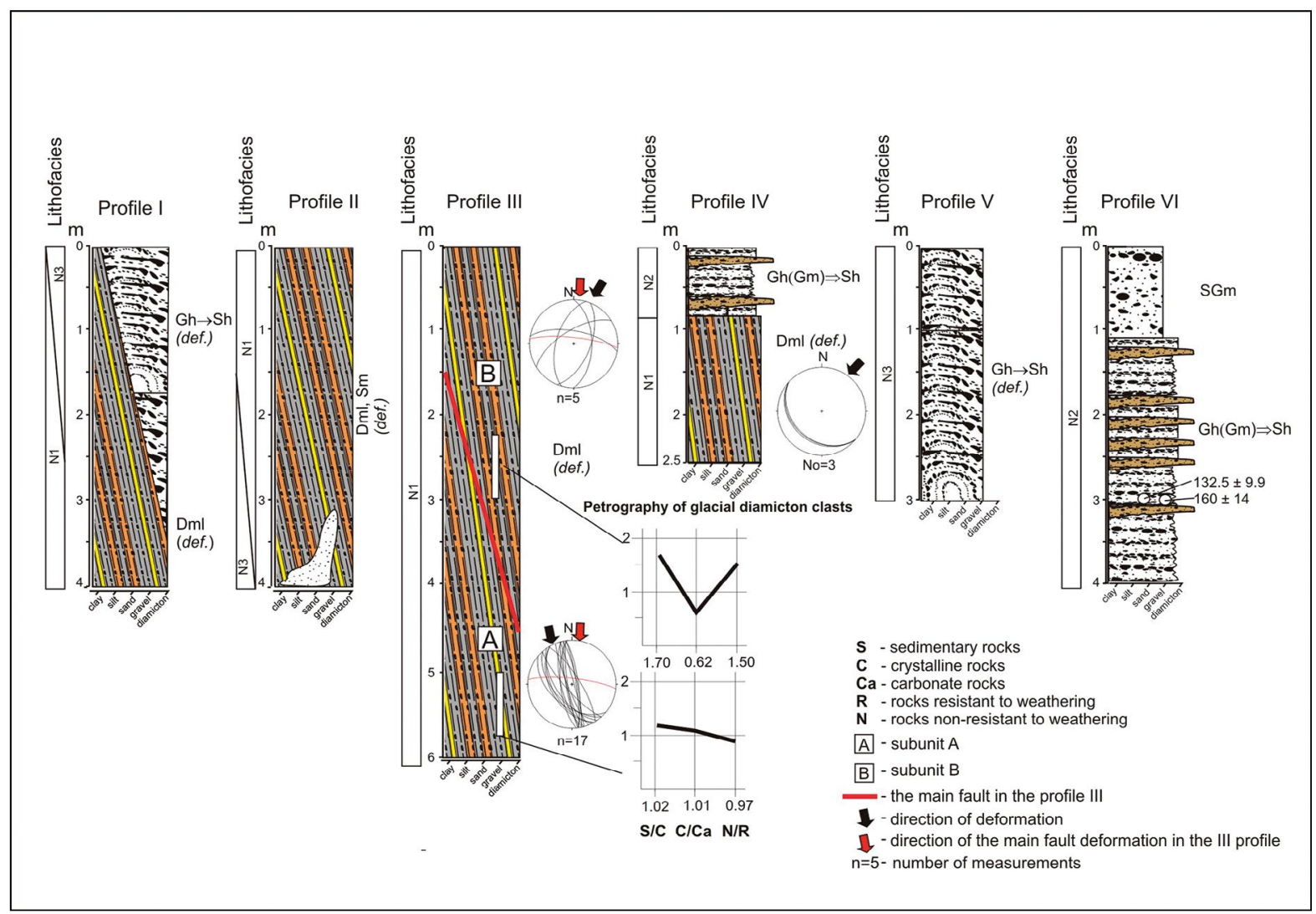

Figure 2. Logs of the Neple site. Lower-hemisphere projections of complementary fracture planes (black colour), the main fault (red colour; great circles) observed in the profile III and azimuth and dip of deformed layers of glacial diamicton in profile IV are shown. Locations of profiles presented in Fig. 1c. For lithofacies explanations see text.

palaeodirections of the ice-sheet advance. The statistics of the fractures and faults measurements were analysed using the Tectonics FP software for Structural Geology, written by Franz Reiter and Peter Acs.

\subsection{Petrography of glacial diamicton clasts}

Petrographic analysis of glacial diamicton was performed to determine the qualitative and quantitative petrographic composition of gravel and to follow these changes in a regional context. The analysis was based on the methodology presented by Wentworth (1922), Böse (1989) and GórskaZabielska (2010). The analysis was intended for determination of areas with strong glacial erosion and indication of transgression directions. It is mainly used for glacial diamicton to assign it into stratigraphic levels (Rzechowski, 1971; Lisicki, 2003). Seven samples of glacial diamicton (at least $0.015 \mathrm{~m}^{3}$ each) were collected from the profiles II and III (Fig. 2) with a use of the furrow method. Each time at least 300 pebbles of the $4.0-10.0 \mathrm{~mm}$ fraction were analysed. They were assigned to 10 petrographic groups. Following coefficients were determined: 1) S/C ratio of sedimentary Palaeozoic rocks (two kinds of limestones, dolomites, shales and quartzitic sandstones) to crystalline rocks and quartz (from disintegrated crystalline rocks); 2) C/Ca ratio of crystalline rocks and quartz (from disintegrated crystalline rocks) to carbonate rocks (limestones and dolomites); 3) N/R ratio of nonresistant (Palaeozoic and Mesozoic limestones, 
dolomites and shales) to resistant rocks (crystalline rocks and quartz from disintegrated crystalline rocks, quartzitic sandstones, quartz and flints). The calculated coefficients were arranged in the order S/C, C/Ca and N/R. As such, it formed a graphic index that enabled correlation of the analysed glacial till with adequate stratigraphic glacial horizons (cf. Kenig, 1998; Lisicki, 2003).

\subsection{Electrical resistivity tomography (ERT)}

By compiling the probing and drilling data, a geological section was constructed, which enabled detailed identification of the geological structure of the sediments. For the purpose of this study, electrical resistivity tomography (ERT) was used, which assures high resolution of the measurements. Volar 96 ERT equipment by ELMES was used. A $40 \mathrm{~m}$ long geophysical profile (Fig. 1c) was performed with 40 measurements made with electrode spacing of $1 \mathrm{~m}$ with a current intensity of 20-200 mA. A symmetrical geoelectric system was applied using the Schlumberger method with $A B$ electrode spacing from $6 \mathrm{~m}$ to $62 \mathrm{~m}$, and using a registration scheme enabling continuous recognition of apparent soil resistance within the depth range of $1-15 \mathrm{~m}$ along the profile. This made it possible to identify the variation in electrical resistivity characteristic of different types of lithological rocks with the direct electric current flowing through these rocks, taking into account the conditions of their occurrence (including flooding). The same lithology, but with unstable water content, results in different conductivity and resistivity readings. In general, dry sediments have higher resistivity compared to moist ones. The data were processed using awa96n software, and the $2 \mathrm{D}$ visualization was performed using the ZondRes2D programs of Zond Software Company (Kaminsky \& Polycina, 2016).

\subsection{Luminescence dating}

The Optically Stimulated Luminescence (OSL) method determines the time elapsed from the last exposure of sediments to daylight (Aitken, 1998) or their heating to a temperature of several hundred $\mathrm{C}^{\circ}$. Determination for two samples from the profile VI (Fig. 1c) was conducted in the Centre of Excellence GADAM of the Institute of Physics, Silesian University of Technology (Moska, 2017). The material was collected in PVC pipes according to the laboratory guidelines and protected with black bags against light. Prior to analysis, 125-200 $\mu \mathrm{m}$ quartz grains were digested first in $20 \%$ hydrochloric acid, followed by a $20 \%$ hydrogen peroxide solution and then $40 \%$ phosphoric acid for $60 \mathrm{~min}$. The method includes stimulation of quartz grains with beta radiation $\left({ }^{90} \mathrm{Sr} /{ }^{90} \mathrm{Y}\right)$ from a calibrated light source. Gamma spectrum measurements were performed to determine the annual radiation dose and each measurement was performed for $24 \mathrm{~h}$. Dose rates were calculated following the geochemical analysis of $\mathrm{U}$, Th and $\mathrm{K}$ concentrations for each sample, using the conversion factors of Adamiec $\&$ Aitken (1998). Cosmic radiation was calculated using the method applied by Prescott \& Stephan (1982), whereas attenuation of beta radiation was calculated using the method provided by Mejdahl (1979). A total of 12 aliquots were made for each sample. Water content (WC) was calculated as the mass of water/mass of dry sediment x100\% (Table 1). The measurements were conducted using luminescence Daybreak 2200 and Risø readers. The absorbed dose was determined using the Single Aliquot Regenerative (SAR) method according to Murray \& Roberts (1998). The final value of the absorbed dose was determined using the Central Age Model (CAM) (Galbraith et al., 1999) (Fig. 3). Two samples were analysed. Samples were collected from ripple-marked and cross-stratified sand (Sr) of the glaciofluvial deposits ( $\mathrm{Sr}$ ). To increase the probability of the result, both samples were collected from the same depth. 
Table 1. Sample information, dosimetry and luminescence age. Depths are given in metres below the outcrop top.

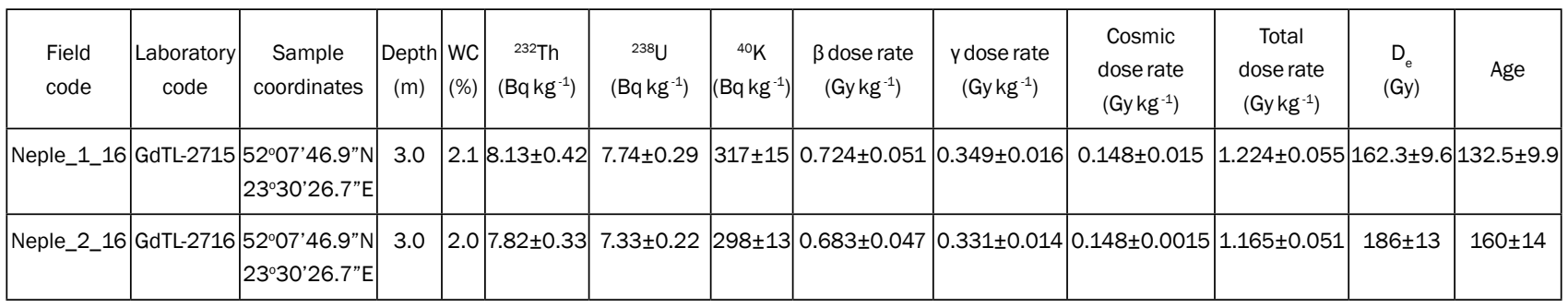
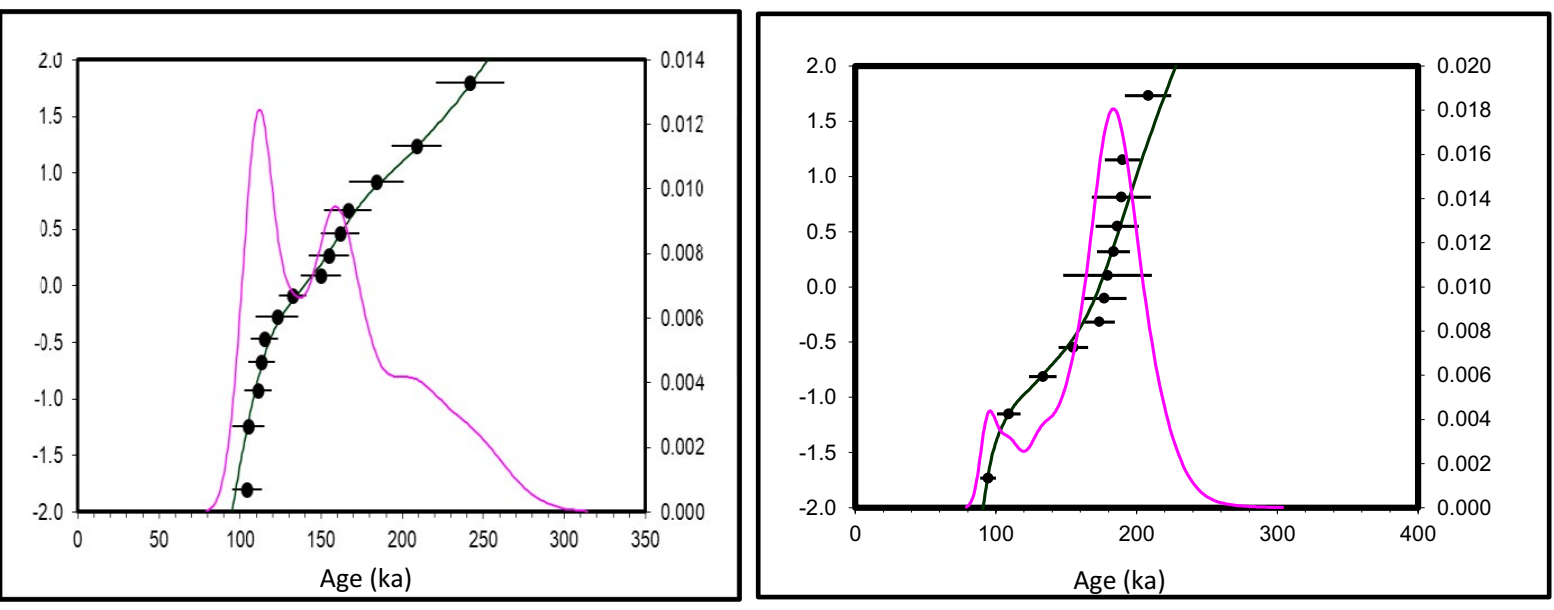

Figure 3. The CAM for samples a) Neple_1_16 (GdTL-2715) and b) Neple_2_16 (GdTL-2716).

\section{Results}

\subsection{Lithological characteristics}

A complex of glaciotectonically deformed glacial and glaciofluvial sediments was found in the Neple site. Three lithofacies were distinguished in 6 profiles (I-VI) based on the detailed sedimentological analysis (Fig. 1c): N1 - stratified glaciotectonically deformed glacial diamicton (Dms), N2 - massive gravel and gravel with sand (Gm, GSm) and $\mathrm{N} 3$ - massive gravel $(\mathrm{Gm})$ and glaciotectonically deformed (Fig. 4a) horizontally stratified sand and gravel with sand (Sh, SGh) (Fig. 2).

Lithofacies N1 is exposed in profiles I-IV and is at least $8 \mathrm{~m}$ thick in profile III, ca. $4 \mathrm{~m}$ thick in profiles I and II, and ca. $2 \mathrm{~m}$ thick in profile IV. It is composed of stratified glacial diamicton (Dms) that consists of three alternating lithofacies: matrix- supported massive clayey grey glacial diamicton (Dmm), matrix-supported laminated brown glacial diamicton (Dml) and well-sorted fine sand with a massive structure $(\mathrm{Sm})$ (Figs. 2, 4a-d). The thickness of the Dmm lithofacies ranges from $2-5 \mathrm{~cm}$ to over $0.5 \mathrm{~m}$, and its top and base layers are usually sharp. In the profile III lithofacies N1 is divided into subunits $\mathrm{A}$ and $\mathrm{B}$. The subunits $\mathrm{A}$ and $\mathrm{B}$ are intersected by a $130^{\circ} / 73^{\circ}\left(220^{\circ} / 73^{\circ} \mathrm{SW}\right)$ fault. The subunit $\mathrm{A}$ is a rhythmite with a sequence of lithofacies: thick layers of Dmm (up to $0.5 \mathrm{~m}$ thick) with sharp tops and base boundaries, thin layers of Dml diamicton (up to $0.3 \mathrm{~m}$ thick) interbedded with layers of the lithofacies $S \mathrm{~m}$ that are $1-2 \mathrm{~cm}$ thick, or the lithofacies $\mathrm{Sm}$ that is composed of layers $1-10 \mathrm{~cm}$ thick or oval structures of very well sorted fine sands with dimensions ranging from $0.2 \times 3.0$ to $4.0 \times 1.0 \mathrm{~m}$. Its characteristic feature is a dense network of complementary fractures in 
Dmm diamicton (Fig. 4b) with the $S_{\mathrm{R}}$ set strikes $170^{\circ}$ and the $S_{L}$ set at $150-155^{\circ}$, together with a presence of gravel to a high degree of weathering. The dihedral acute angle between $S_{R}$ and $S_{L}$ sets is ca. $20^{\circ}$ (Fig. 2). The dihedral acute angle between $S_{R}$ and $S_{L}$ sets represents a double value of the shear angle $(2 \theta)$ (Ramsay \& Huber, 1984; Dadlez \& Jaroszewski, 1994). The bisector of this angle marks the position of the maximum compression axis $\sigma_{1}$. On the average the angle $\theta$ is $-30^{\circ}$ and it means that in the subunit A the faults represent hybrid extension/ shear conditions (Konon, 2004). Glaciotectonic deformations (maximum compressive stress $-\sigma_{1}$ ) of sediments in the subunit A of the profile III suggest the stress from the northwest (Fig. 2).

The subunit B forms most of all the $\mathrm{Dml}$ lithofacies which consists of alternating laminae of massive silty-clayey diamicton and silty sand, both $1-3 \mathrm{~cm}$ thick. A total thickness of the Dml lithofacies varies from a few centimetres to over $1 \mathrm{~m}$ and there are intercalations of thin layers of grey Dmm diamicton up to $0.3 \mathrm{~m}$ thick (Fig. 4c). Tops and bases layers of these sediments are irregular but sharp. These sediments form a rhythmite with a sequence of lithofacies $\mathrm{Dmm} \Rightarrow \mathrm{Dml} \Rightarrow \mathrm{Sm}$ and $\mathrm{Dmm} \Rightarrow \mathrm{Sm}$, repeated in the profile III at least 25 30 times and deflected from its original position in folds, most likely with large amplitude and small radius (Fig. 4c). Similar as in the subunit A, in the subunit B there are complementary fractures in Dmm diamicton with two directional maxima of $0^{\circ}$ and $40^{\circ}$, corresponding to $S_{L}$ and $S_{R}$ set strikes (Fig. 4b). These glaciotectonic deformations (maximum compressive stress $\sigma_{1}$ ) and intersected by $130^{\circ} / 73^{\circ}\left(220^{\circ} / 73^{\circ} \mathrm{SW}\right)$ fault in the subunit $\mathrm{B}$ suggest the ice sheet movement from $\mathrm{N}$ and NNE (Fig. 2). Similar sediments were found in the profile IV where the layer spread ranges from $130^{\circ}-132^{\circ} / 29^{\circ}-34^{\circ}\left(220-223^{\circ} / 29^{\circ}-34^{\circ} \mathrm{S}\right)$, and it corresponds to the orientation of the fault plane identified in the N1 sediments (Fig. 2).

Results of the petrographic analysis of gravel from the massive grey glacial diamicton (Dmm) of the lithofacies N1 from the lower part of the profile III (Fig. 2) indicate that the values of the S/C-C/Ca-N/R coefficients are 1.02-1.01-0.97 and correlate with the petrographic lithotype S2, typical for the Elsterian Glaciation (MIS 12) (Lisicki, 2003). A brown glacial diamicton (Dml) collected from the upper part of the same wall with a southwestern exposure at an earlier stage of pit exploitation was also analysed. Values of the coefficients were $1.70-0.62-1.50$, corresponding to the lithotype W of the Saalian Glaciation (MIS 6) (Lisicki, 2003). Presence of these two types of the glacial diamicton (Dmm and $\mathrm{Dml}$ ) of different ages was previously demonstrated at the study site based on petrographic studies of Gałązka (2004) and Czubla et al. (2013).

The lithofacies $\mathrm{N} 2$ was documented only in the profiles IV and VI, in the NE wall of the excavation pit (Figs. 1c, 2). It is composed of massive gravel (Gm), horizontally stratified gravel with sand (Sh, SGh), massive sand (Sm) and ripple-marked cross-stratified sand ( $\mathrm{Sr}$ ). Their bases and tops are sharp and eroded, approximately $15 \mathrm{~cm}$ thick. The sediments form a rhythmite with a sequence of lithofacies $\mathrm{Gm} \Rightarrow \mathrm{Sh}$ and $\mathrm{SGh} \Rightarrow \mathrm{Sh}(\mathrm{Sr})$, repeating ca. 15-20 times, and they are overlain by massive sandy gravel with dispersed grain skeleton $(\mathrm{Gm})$ $0.9 \mathrm{~m}$ thick (Marks \& Karabanov, 2017). The $\mathrm{N} 2$ glaciofluvial sediments in the profile VI were OSL-dated at $132.5 \pm 9.9$ (GdTL-2715) to $160 \pm 14$ ka (GdTL-2716). A discrepancy between these ages is probably due to the differences in the grain size composition of the dated sediment, and thus different conditions of sediment transport (Weckwerth et al., 2013).

Profiles I, II and V reveal sediments of the lithofacies N3 (Fig. 4), consisting of horizontally stratified sand (Sh) and gravel (Gh) or massive gravel with sand (GSm) and horizontally stratified sand (Sh), ca. $15 \mathrm{~cm}$ thick, and occasionally massive sand $(\mathrm{Sm})$. Sediments form a rhythmite with a sequence of lithofacies $\mathrm{Gm}(\mathrm{Sm}) \Rightarrow$ ShlubSGm $\Rightarrow$ Sh and are affected by glaciotectonic deformations. 

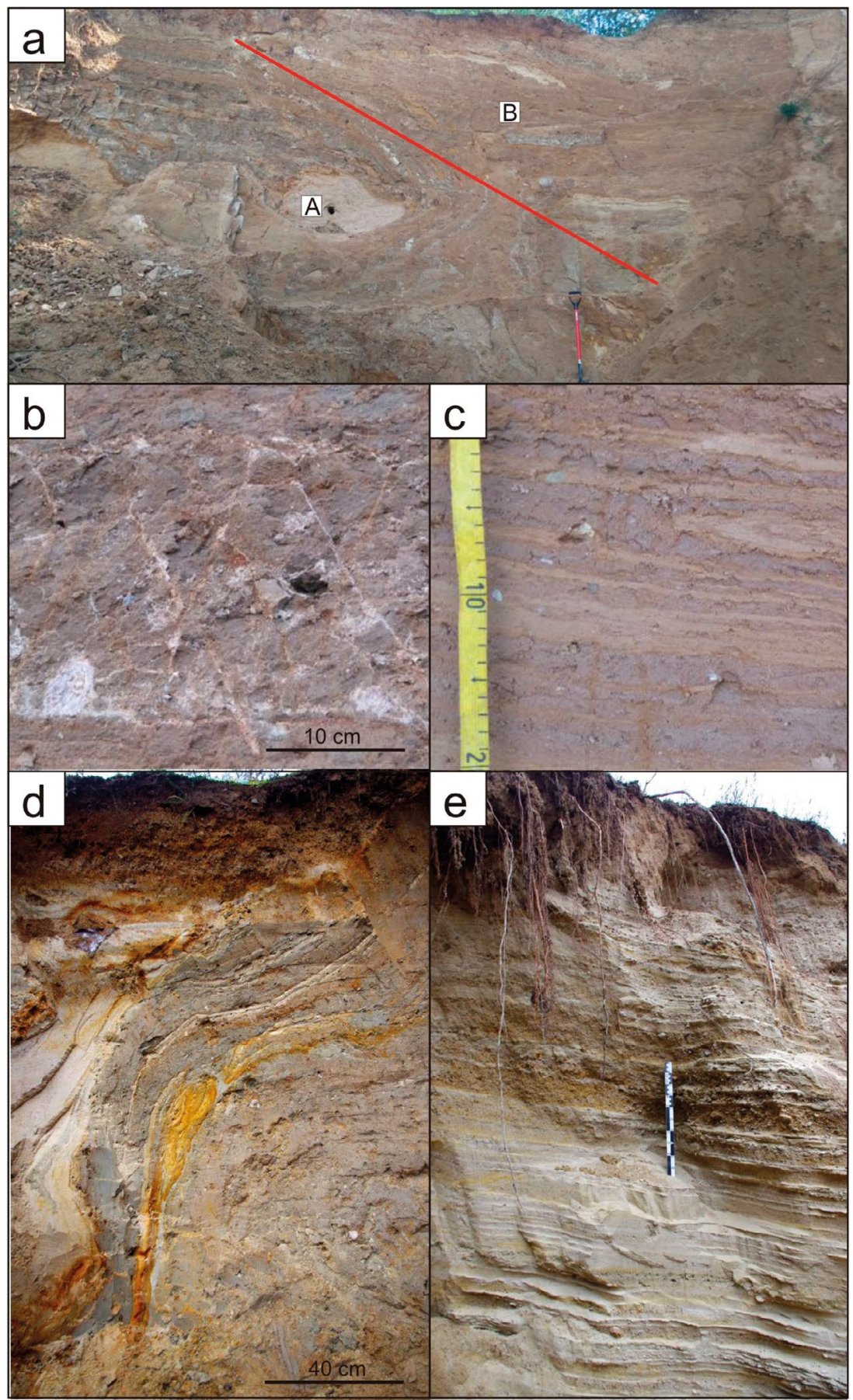

Figure 4. The Neple site outcrop: a) a deformed glacial diamicton intersected by a $130^{\circ} / 73^{\circ}\left(220^{\circ} / 73^{\circ} \mathrm{SW}\right)$ fault (red line) and divided into subunits $A$ and $\mathrm{B}$; b) the network of complementary fractures in grey massive glacial diamicton (Dmm); c) matrix-supported brown laminated glacial diamicton (Dml) and well-sorted massive fine sand (Sm); d) deformed glacial diamicton; e) horizontally stratified sand and gravelly sand (Sh, SGh) and massive gravel (Gm). For lithofacies explanations see text. 


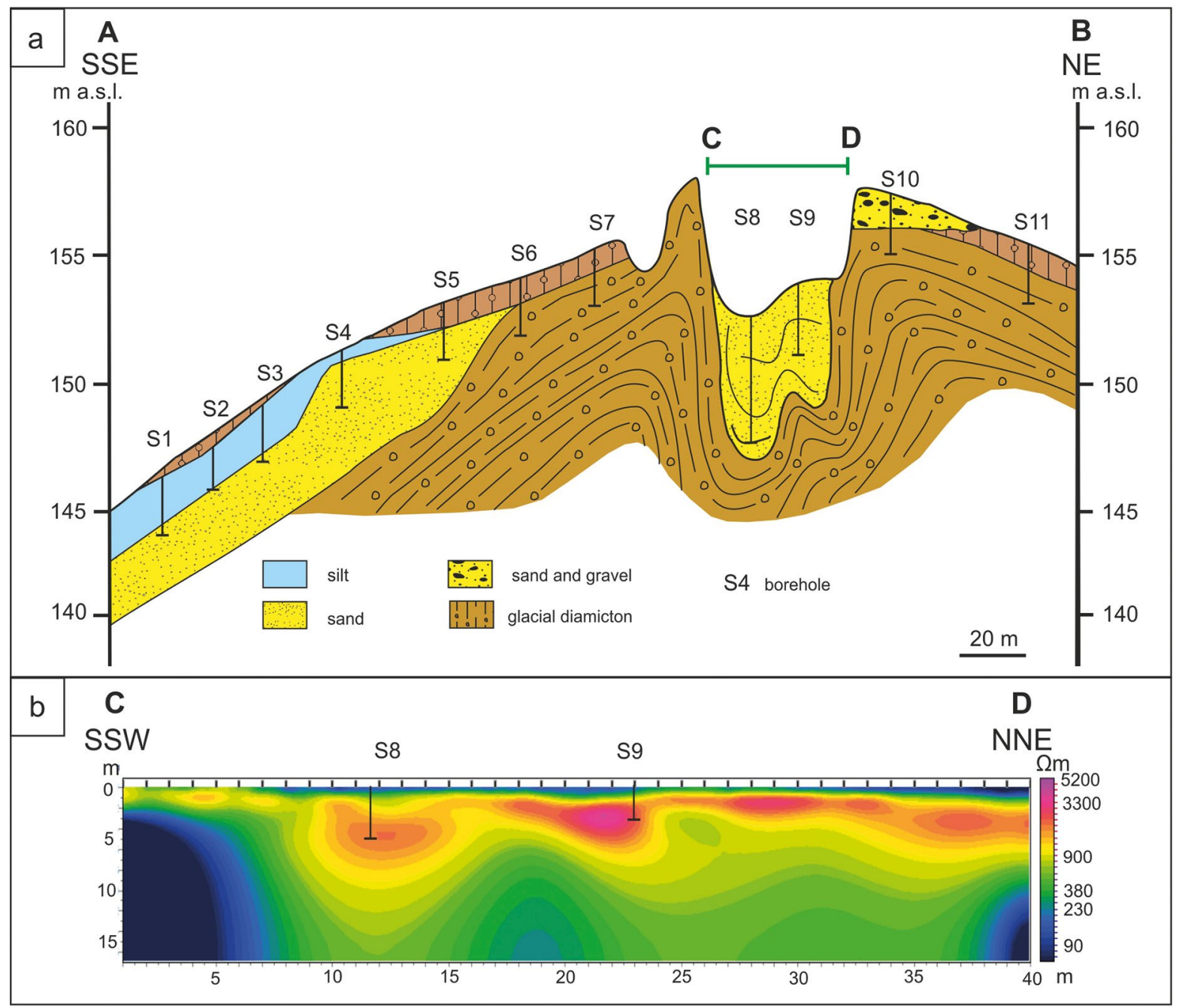

Figure 5. a) A geological cross-section of the Neple area. b) A geophysical profile across the Neple outcrop.

\subsection{Electrical resistivity tomography (ERT)}

The results of electrical resistivity tomography (ERT), penetrating to $5 \mathrm{~m}$ depth and drillings allowed for detailed identification of a geological structure in the immediate surroundings of the Neple site (Fig. 4). The glacial diamicton (resistivity $<90 \Omega \mathrm{m})$ is vertically distributed in the SW wall of the outcrop to several metres depth and it was not found at a distance of $10 \mathrm{~m}$ from the SW wall of the excavation pit (Fig. 5a, b). Low-resistivity sediments that occur in the centre and near the $\mathrm{NE}$ wall, represent a glacial diamicton forming a fold, and the overlying sands (average resistivity $-400 \Omega \mathrm{m}$ ) and sands with gravel (average resistivity $2000 \Omega \mathrm{m})$ form upright folds. The lithofacies $\mathrm{N} 1$ and N3, which are affected by glaciotectonic deformations, are much thicker compared to those exposed in the outcrop (Fig. 2; Fig. 5a, b). 


\section{Discussion}

A number of landforms and glaciotectonic deformations occur along the left bank of the Bug River valley from Janów Podlaski to Neple site (Fig. 1a) and they can be associated with the maximum ice-sheet advance of the Warta Stadial (MIS 6). In the marginal zone of this ice-sheet, a clear subdivision into glacial lobes was marked, similarly as in the region of northern Podlasie (Rychel \& Morawski, 2017) and in central Poland (Klatkowa, 1996; Rdzany, 2008; Dzieduszyńska et al., 2014). At the same time, numerous sites with biogenic sediments of the Mazovian Interglacial with no cover of glacial deposits can be found west of the Bug valley and in Belarus (Gursky, 1974; Marks et al., 2018).

The Warta Stadial ice-sheet conditions during its maximum advance are likely preserved at the Neple site. The stratified glacial diamicton (Dms, lithofacies N1; Fig. 2) at the Neple site indicates erosion of the older glacial till (glacial diamicton as the substratum of the advancing ice-sheet advance). The brown glacial diamicton (Dml), separating the massive grey glacial diamicton $(\mathrm{Dmm})$ and containing well-preserved layers of very well sorted fine sand, indicates (Fig. 4a-d) deposition in places where the ice-sheet was decoupled from the substrate/underlying glacial diamicton and where basal sliding over a thin water layer predominated (Piotrowski \& Tulaczyk, 1999; Piotrowski et al., 2006; Narloch et al., 2014). The increase in pressure of subglacial waters under the ice-sheet could result from presence of the older clayey glacial diamicton (Dmm) of the Elsterian Glaciation (MIS 12), eroded by the Warta Stadial ice-sheet of the Odranian Glaciation (Saalian, MIS 6) during its advance (e.g. Evans et al., 2006). Deformation processes occurred in places where the brown glacial diamicton $(\mathrm{Dml})$ is more homogeneous or the sediment has transitional features between diamicton and sand. The thickness of the deforming layer was probably small and did not exceed a few centimetres.
Sediments of the lithofacies N1 and N3 are glaciotectonically deformed. This means that the deformations occurred after the accumulation of the rhythmite with the $\mathrm{Dmm} \Rightarrow \mathrm{Dml} \Rightarrow \mathrm{Sm}$ and $\mathrm{Dmm} \Rightarrow \mathrm{Sm}$ sequence of lithofacies, which forms also a glacial diamicton of the Warta Stadial of the Odranian Glaciation (Saalian, MIS 6), as a result of readvance of the ice-sheet front.

This supports the results obtained by Klatkowa (1996) and Rdzany (2008) from central Poland, where the greatest deformation activity of the ice-sheet of the Warta Stadial (MIS 6) was not associated with the main glacial advance, but took place during the cataglacial phase of this glaciation, when short-lived surges of the icesheet front occurred. A direction of glaciotectonic deformations determined based on analysis of the lithofacies $\mathrm{N} 1$ in the subunits $\mathrm{A}$ and $\mathrm{B}$ indicates univocally that there were at least 2 ice sheet advances from the northwest, followed by the readvance from the north and northeast (Fig. 4). This is proven by the character of the deformed sediments, including presence of hybrid faults in the subunit $A$, origin of which was connected with ice sheet advance from the northwest. Measurements of the deformation structures in the subunit B indicate that the ice-sheet readvanced from the $\mathrm{N}$ and encountered resistance by, e.g., the glacial lobe in the present-day river-mouth section of the Krzna valley. A formation of complementary fractures in the massive glacial grey diamicton (Dmm) is associated with intensity of a local stress field from the NW. The fault in lithofacies N1 with the azimuth of $130^{\circ}$ shows that the local ice-sheet advanced from N. Faults are associated with different glaciotectonic stages and are probably a part of a larger complex involved in the deformation, dominated by plastic deformation in the form of upright folds with varying amplitude. It means that a frontal part of the ice sheet of the Warta Stadial (MIS 6) was unstable at its maximum extension.

A final stage of the push moraine formation at Neple during the retreat of the Warta Stadial 


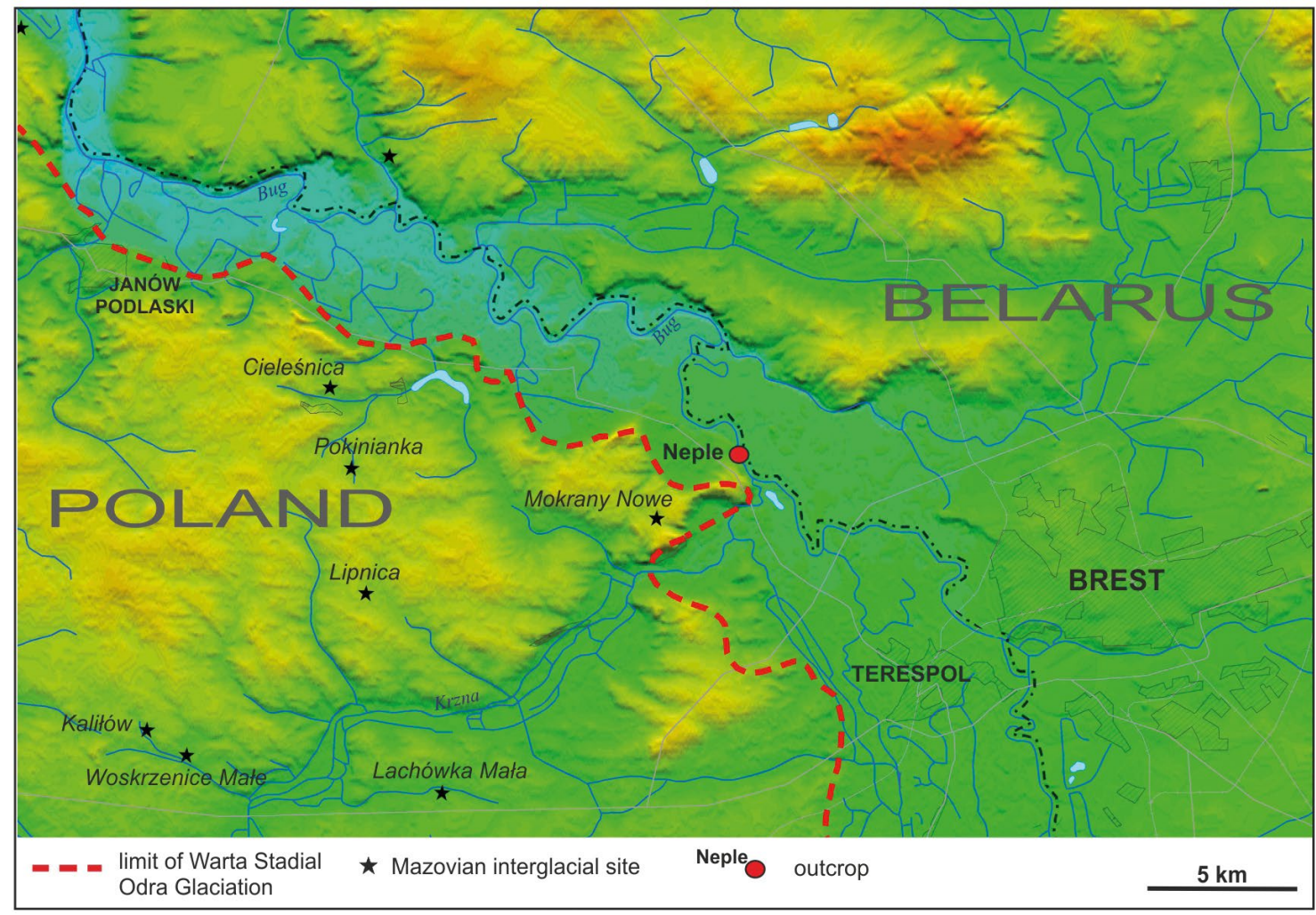

Figure 6. Location of the Neple site and ice-sheet limit of the Warta Stadial, together with the sites of the Mazovian Interglacial deposits without the glacial cover.

ice-sheet is the accumulation of sediments of the lithofacies N2 (Fig. 2) in a proximal part of the glaciomarginal fan, dominated by sheet floods. The maximum surge is recorded in massive gravel $(\mathrm{Gm})$ or massive sand $(\mathrm{Sm})$, whereas subsidence of the flood wave is reflected in the lithofacies $\mathrm{Sh}$ and SGh (cf. Pisarska-Jamroży, 2008). The icesheet of the Warta Stadial (Saalian, MIS 6) was considerably active in its marginal zone in eastern Poland, both during its maximal advance and retreat, whereas its front was split into several lobes (Włodarski \& Godlewska, 2016; Rychel et al., 2015; Rychel \& Morawski, 2017). Due to a presence of a large channelled depression in the Bug valley, the landform where the Neple site is located is composed of a glacial diamicton that was glaciotectonically deformed in a direct vicinity of the ice-sheet margin of the Warta Stadial (Nitychoruk \& Gałązka, 1994; Gałązka, 2004; Czubla et al., 2013, Marks \& Karabanov, 2017). Numerous sites with organic sediments of the Mazovian Interglacial that are not covered by a glacial till, are located to the south of the Bug River, and petrographic studies of the glacial till, among others at the Neple site, contributed to the revision of the maximum extent of the Warta Stadial icesheet in this area (Figs. 1a, 6) (Marks et al., 2018).

\section{Conclusions}

Petrographic studies carried out at the Neple site have proved that the glacial diamicton is of two different ages, representing the Elsterian and the 
Saalian (Warta Stadial) glaciations. Deformation of the lithofacies N1 sediments (including glacial diamicton) confirms the direction of the ice-sheet advance from northwest and readvance from the north and northeast and further suggests icedamming by a glacial lobe to the southwest within a large depression, currently used by the Krzna River. Most likely, deformation was connected with a cataglacial phase of this glaciation, when shortterm activations of the ice-sheet front occurred. Sediments of the Kamienna Baba Mount record the ice-sheet front activity during the maximum extent of the Warta Stadial. Geological setting of glacial deposits in this area can be determined univocally by their relation to the sediments of the Holsteinian and Eemian interglacials. End moraines to the southeast of Mielnik, glaciotectonic deformations in the southwestern scarp of the Bug River valley at Neple and meltwater runoff towards the southeast suggest that a glacial lobe occurred during the

\section{References}

Adamiec, G. \& Aitken, M. J., 1998. Dose-rate conversion factors: update. Ancient TL 16, 37-50.

Aitken, M.J., 1998. An Introduction to Optical Dating: The Dating of Quaternary Sediments by the Use of PhotonSimulated Luminescence. Oxford University Press, Oxford, 276p.

Baraniecka, M.D., Lindner, L., Makowska, A., Mojski, J.E., Szczepankiewicz, S., Starkel, L. \& Watycha, L., 1984. Budowa geologiczna Polski, 1; stratygrafia, 3b, kenozoik, czwartorzęd. Wydawnictwa Geologiczne, Warszawa, 396 p. (in Polish)

Ber, A., 2006. Glacitectonic map of Poland 1: 1000000 Państwowy Instytut Geologiczny, Warszawa.

Böse, M., 1989. Methodisch-stratigraphische Studien und paläomorphologische Untersuchungen zum Pleistozän südlich der Ostsee. Berliner Geographische Abhandlungen 51, 114 p. (in German)

Czubla, P., Godlewska, A., Terpiłowski, S., Zieliński, T., Zieliński, P., Kusiak, J., Pidek., I.A. \& Małek, M., 2013. Glacial till petrography of the South Podlasie Lowland (E Poland) and stratigraphy of the Middle Pleistocene Complex (MIS 11-6). In: Damušyte, A. \& Grigienè, A. (eds.), Palaeolandscapes from Saalian to Weichselian, South Eastern Lithuania. Abstracts. Vilnius, 25-30.

Dadlez, R. \& Jaroszewski, W., 1994. Tektonika. Wydawnictwo Naukowe PWN, Warszawa, 744 p. (in Polish)
Saalian Glaciation in the present Bug River valley in the vicinity of Brest (Zaborski, 1927; Marks et al., 2018). The lobate ice-sheet limit during the Warta Stadial and its dynamics recorded at Neple could be an effect of a stream-like pattern of the ice-sheet during the Saalian Glaciation. The runoff of glacial meltwaters and extraglacial waters during the Warta Stadial turned to the east, toward the Pripyat River valley and then, to the Dnieper River valley.

\section{Acknowledgements}

The authors are grateful to Dr. Ola Fredin (Geological Survey of Norway) and an anonymous reviewer for careful reading of our manuscript and helpful comments and suggestions. The project was funded by the National Science Centre in Poland (decision no. DEC-2013/09/B/ST10/02040; project no. UMO-2013/09/B/ST10/02040).

Dzieduszyńska, D., Petera-Zganiacz, J., Roman, M. \& Wachecka-Kotkowska, L., 2014. Glacial-interglacial cycles in Central Poland as reflected in the Łódź University geomorphological scientific achievements. In: Kobojek, E. and Marszat, T. (eds), Origin of relief of central Poland and its anthropogenic transformation in Łódź, University Geographical, 29-56.

Evans, D.J.A., Phillips, E.R., Hiemstra, J.F. \& Auton, C.A., 2006. Subglacial till: Formation, sedimentary characteristics and classification. Earth-Science Reviews 78, 115-176.

https://doi.org/10.1016/j.earscirev.2006.04.001

Galbraith, R.F., Roberts, R.G., Laslett, G.M., Yoshida, H. \& Olley, J.M., 1999. Optical dating of single and multiple grains of quartz from Jinminum Rock Shelter, Northern 12 Australia. Part I, experimental design and statistical models. Archaeometry 41, 1835-1857. https://doi.org/10.1111/j.1475-4754.1999.tb00987.x

Galon, R. \& Roszkówna, L., 1961. Extents of the Scandinavian glaciations and of their recession stages on the territory of Poland in the light of an analysis of marginal forms of inland ice. Przegląd Geograficzny 33, 347-364.

Gałązka, D., 2004. Zastosowanie makroskopowych badań eratyków do określenia stratygrafii glin lodowcowych środkowej i północnej Polski. PhD Thesis Uniwersity of Warsaw, Poland, 255 p. (in Polish) 
Górska-Zabielska, M., 2010. Petrographic study of glacial sediments - an outline of the problem. Landform Analysis 12, 49-70.

Gursky, B. N., 1974. Nizhnyi i sriednyi antropogen Bielarussii. Nauka i Technika, Minsk, 142 p. (in Russian)

Kaminsky, A.E. \& Polycina, A.V., 2016. Тотальная инверсия данных малоглубинных геофизических исследований. 12th Conference and Exhibition Engineering Geophysics. (in Russian) https://doi.org/10.3997/2214-4609.201600291

Kenig, K., 1998. Petrograficzne podstawy stratygrafii glin morenowych Polski północno-wschodniej. Biuletyn Państwowego Instytutu Geologicznego 380, 1-99. (in Polish)

Klatkowa, H., 1996. Elementy glacitektoniczne w budowie geologicznej i rzeźbie podłódzkiej części środkowej Polski, Acta Geographica Lodziensia 72,7-103. (in Polish)

Konon, A., 2004. Successive episodes of normal faulting and fracturing resulting from progressive extension during the uplift of the Holy Cross Mountains, Poland. Journal of Structural Geology 26, 419-433.

https://doi.org/10.1016/j.jsg.2003.08.004

Lisicki, S., 2003. Lithotypes and lithostratigraphy of tills of the Pleistocene in the Vistula drainage basin area, Poland. Prace Państwowego Instytutu Geologicznego 177, 105 p.

Marks, L. \& Karabanov, A. (eds.), 2017. Geological map of Polish-Belarus cross-border area Biała Podlaska and Brest region 1: 250 000. Polish Geological Institute - National Research Institute, Warsaw.

Marks, L. \& Pavlovskaya, I.E., 2006. Correlation of the Saalian glacial limits in eastern Poland and western Belarus. Quaternary International 149, 87-93. https://doi.org/10.1016/j.quaint.2005.11.021

Marks, L., Karabanov, A., Nitychoruk, J., Bahdasarau, M., Krzywicki, T., Majecka, A., Pochocka-Szwarc, K., Rychel, J., Woronko, B., Zbucki, Ł., Hradunova, A., Hrychanik, M., Mamchyk, S., Rylova, T., Nowacki, Ł. \& Pielach, M., 2018. Revised limit of the Saalian ice sheet in central Europe. Quaternary International 478, 59-74. https://doi.org/10.1016/j.quaint.2016.07.043

Matveyev, A.V., 1995. Glacial history of Belarus. In: Ehlers, J.,Kozarski, S., Gibbard, Ph. (eds.), Glacial deposits in north-east Europe. Balkema, Rotterdam-Brookfield, 267-276.

Mejdahl, V., 1979: Thermoluminescence dating: beta-dose attenuation in quartz grains. Archaeometry 21, 61-72. https://doi.org/10.1111/j.1475-4754.1979.tb00241.x

Mojski, J.E., 1972. Nizina Podlaska. In: Galon R. (ed.), Geomorfologia Polski 2. PWN, Warszawa, 318-362. (in Polish)

Moska, P., 2017. Datowanie luminescencyjne metoda OSL 111 próbek osadów czwartorzędowych. Raport, NAG Polish Geological Insitute-National Research Institute, Warsaw 117 p. (in Polish)
Murray, A.S. \& Roberts, R.G., 1998. Measurement of the equivalent dose in quartz using a regenerative-dose singlealiquot protocol. Radiation Measurements 29, 503-515. https://doi.org/10.1016/s1350-4487(98)00044-4

Narloch, W., Wojciechowska, J.M., Osowicka, A., Wysota, W., Piotrowski, J.A. \& Sobiech, M., 2014. Zróżnicowanie facjalne glin jako wskaźnik fluktuacji ciśnienia wód subglacjalnych na kontakcie lodu i podłoża podczas zlodowacenia wisły w północnej części Pojezierza Dobrzyńskiego. Landform Analysis 25, 125-133. (in Polish) https://dx.doi.org/10.12657/landfana.025.011

Nitychoruk J., 1994. Stratygrafia plejstocenu i paleogeomorfologia południowego Podlasia. Rocz. Międzyrzecki 26, 23-107. (in Polish)

Nitychoruk, J. \& Gałązka, D., 1994. Profil osadów glacjalnych w okolicach Nepli. Przewodnik 43 Zjazdu PT Geogr. 99-103. (in Polish)

Nitychoruk, J., Dzierżek, J. \& Stańczuk, D., 2007a. Szczegółowa Mapa Geologiczna Polski w skali 1: 50,000, arkusz Janów Podlaski (532). Państwowy Instytut Geologiczny, Warszawa. (in Polish)

Nitychoruk, J., Dzierżek, J. \& Stańczuk, D., $2007 \mathrm{~b}$. Szczegółowa Mapa Geologiczna Polski w skali 1:50000, arkusz Terespol (570). PaństwowyInstytut Geologiczny, Warszawa. (in Polish)

Piotrowski, J.A. \& Tulaczyk, S., 1999. Subglacial conditions under the last ice sheet in northwest Germany: ice-bed separation and enhanced basal sliding? Quaternary Science Reviews 18, 737-751.

https://doi.org/10.1016/S0277-3791(98)00042-0

Piotrowski, J.A., Larsen, N.K., Menzies, J. \& Wysota, W., 2006. Formation of subglacial till under transient bed conditions: deposition, deformation, and basal decoupling under a Weichselian ice sheet lobe, central Poland. Sedimentology 53, 83-106. https://doi.org/10.1111/j.1365-3091.2005.00755.x

Pisarska-Jamroży M., 2008. Mechanizmy depozycji w strefie glacimarginalnej zlodowacenia Wisły. Studium sedymentologiczne z Pomorza Zachodniego i Jutlandii. Wyd. Uniw. Kazimierza Wielkiego, Bydgoszcz. (in Polish)

Prescott, J.R. \& Stephan, L.G., 1982. The contribution of cosmic radiation to the environmental dose for thermoluminescence dating. Latitude, altitude and depth dependencies. PACT, 6, 17-25.

Ramsay, J.G. \& Huber, M.I., 1984. The techniques of modern structural geology, vol 1. Strain analysis. Academic Press, London, $307 \mathrm{p}$.

Rdzany, Z., 2009. Rekonstrukcja przebiegu zlodowacenia warty w regionie łódzkim. Wydawnictwo Uniwersytetu Łódzkiego, Łódź, 310 p. (in Polish)

Rychel, J. \& Morawski, M., 2017. Postglacial morpholineaments as an indicator of ice sheet dynamics during the Saale Glaciation in the Białystok Plateau and Sokółska 
Hills (NE Poland). Geological Quarterly 61, 335-350. https://doi.org/10.7306/gq.1352

Rychel, J., Woronko, B., Karasiewicz, T., Szymczuk, P. \& Morawski, M., 2015. Ice-sheet dynamics of Wartha Glaciation (Saale) in the marginal zone of Knyszewicze area, North Eastern Poland. Studia Quaternaria 32, 7990 .

https://doi.org/10.1515/squa-2015-0007

Rzechowski, J., 1971. Granulometryczno-petrograficzne własności glin zwałowych w dorzeczu środkowej Widawki. Biuletyn PIG 254, 111-155. (in Polish)

Terpiłowski, S. \& Dobrowolski, R., 2004. Rola morfologii dolinnej w rozwoju moren akumulacyjnych lobu Bugu zlodowacenia warty w rejonie Mielnika (Wysoczyzna Drohicka). In: Harasimiuk, M. and Terpiłowski, S. (eds.), Zlodowacenie warty w Polsce. Wyd. UMCS, Lublin, 153-161. (in Polish)

Tsapenko, M. \& Makhnach, N., 1959. Antropogen deposits of Byelorussia. Naukaitekhnika, Minsk, $225 \mathrm{p}$.

Weckwerth, P., Przegiętka, K.R., Chruścińska, A. \& PisarskaJamroży, M., 2013.The relation between optical bleaching and sedimentological features of fluvial deposits in the Toruń Basin (Poland). Geological Quarterly, 57,31-44.

https://doi.org/10.7306/gq.1074
Wentworth, C. K., 1922. A scale of grade and class terms for clastic sediments. Journal of Geology, 30, 377-392. https://doi.org/10.1086/622910

Włodarski, W. \& Godlewska, A., 2016. Sedimentary and structural evolution of a Pleistocene small-scale push moraine in eastern Poland: new insight into palaeoenvironmental conditions at the margin of an advancing ice lobe. Quaternary Science Reviews 146, 300-321. https://doi.org/10.1016/j.quascirev.2016.06.014

Woronko, B., Belzyt, S., Bujak, Ł. \& Pisarska-Jamroży, M., this volume. Glaciotectonically deformed glaciofluvial sediments with ruptured pebbles (Koczery study site, E Poland). Bulletin of the Geological Society of Finland, this volume. https://doi.org/10.17741/bgsf/90.2.001

Zaborski, B., 1927. Studia nad morfologią dyluwium Podlasia i terenów sąsiednich. Przegląd Geograficzny 7, 1-52. (in Polish)

Zieliński, T. \& Pisarska-Jamroży, M., 2012. Jakie cechy litologiczne warto kodować, a jakie nie? Przegląd Geologiczny 60, 387-397. (in Polish) 